\title{
A Survey of Factors Affecting the Successful Implementation of Technology in Teaching ${ }^{\#}$
}

\author{
Artan Luma *1, Besnik Selimi ${ }^{\text {**1 }}$, Satki Ismaili ${ }^{* * * *}$
}

Accepted $15^{\text {th }}$ August 2014

\begin{abstract}
The technology has changed the way people live, learn and work. Successful usage of technology in education is an important challenge, for different reasons. In one hand, children should be acquainted with ICT and develop competencies and skills from their younger age to face with the challenges of 21 centuries. In other hand, it has been shown that the usage of ICT can increase the quality of teaching and that traditional methods are no longer in position to fulfill students' needs. The technology can offer a wider access to knowledge, adapted and personalized to the individual skills and interests of each student. The implementation of this technology requires technical infrastructure, adequate preparation of teaching staff for the use of resources and adaptation of teaching didactics based on modern technology. In this paper, we present a survey of different factors that influence the successful implementation of ICT in teaching.
\end{abstract}

Keywords: Technology, education, teaching, learning, ICT.

\section{Introduction}

In the process of teaching and learning, there are many factors affecting the quality of teaching and the development of ICT competencies and skills, among which are: the capacities of ICT in schools, teacher professional development, teacher demographics, ICT skills and knowledge's, teacher's attitude and incentive, the assessment of student's achievements, the acquisition of ICT knowledge and professional application of knowledge by students.

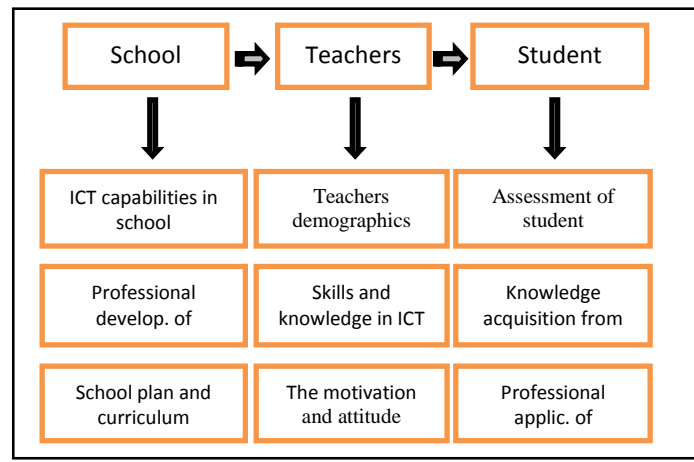

Figure 1. Factors that affect the successful implementation of ICT in teaching.

The transformation of the educational system, with the use of information and communication technology, enables successful

${ }^{1}$ Contemporary Sciences and Technologies, South East European University, Campus, 1200, Tetovo/Macedonia

*Corresponding Author: Email: a.luma@seeu.edu.mk

** Corresponding Author: Email: b.selimi@seeu.edu.mk

***Corresponding Author: Email: si21635@seeu.edu.mk

\# This paper has been presented at the International Conference on

Advanced Technology\&Sciences (ICAT'14) held in Antalya (Turkey), August 12-15, 2014. integration of students as future citizens in the global information society. Some preconditions must be fulfilled to attain this transformation which main pillar is the information and communication technology.

The preconditions are:

- Domestic and international standards in the field of eeducation that fit with practices and guidelines of the European Union.

- The legislation that enables the realization of necessary activities based on the legal framework.

The marketing and quality control for monitoring the quality of activities and their performance [1].

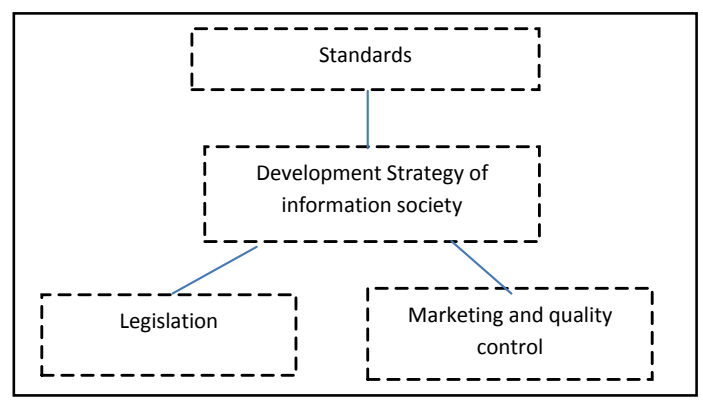

Figure 2. Standards implementation of ICT in the teaching process.

Over the past three decades, governments and educational systems around the world have considered the use of information and communication technology (ICT) as an important issue for improving the effectiveness of teaching and learning.

In Republic of Macedonia this issue is very important. To meet the goals of the implementation of information and communication technology in teaching system, there is a constant coordination of relevant subjects related to education such as the Ministry of Education and Science of the Republic of Macedonia, 
Ministry of Information Society and Administration, Research centres and institutes, primary and secondary schools, continuing education centres, etc.

For this purpose there is a Programme for the development of information and communication technology in education [2]. In order to have a real insight on the factors that affect the successful implementation of Information and Communication Technology in the teaching process in the Republic of Macedonia, I have conducted research with 620 teachers in December 2013 for following factors:

- The capacities of ICT in school

- Professional development of teachers

- $\quad$ School Planning

- Teacher Demographics

- $\quad$ Skills and knowledge about ICT

- Motivation and attitude of teachers

- $\quad$ Assessment of student achievements

- $\quad$ Acquiring knowledge about ICT

- Professional application of student's knowledge

\section{ICT Capacities in Schools}

Statistical data have shown that in the Republic of Macedonia, school infrastructures meet the requirements for use of technology in teaching and learning education process. The largest numbers of schools have laboratories for the implementation of teaching the subject of Informatics and schools are provided with computers from the Government Project "A computer for every child". Only in the first quarter of 2013, 66 schools were provided Smart Boards for implementation of the learning process with modern technology.

The results of a survey show that $71 \%$ of schools have IT labs, while $29 \%$ of them do not have them; $69 \%$ of classrooms are supplied with computers, and $31 \%$ are not. Among 620 interviewed students, 569 students or $92 \%$ have laptops, while $51 \%$ or $8 \%$ do not have laptops.

$76 \%$ of schools possess printers, and $24 \%$ of them do not have printers. $96 \%$ possess LCD projectors, while $4 \%$ do not possess them. $27.5 \%$ of schools possess Smart Boards, while $72.5 \%$ do not have them. $98 \%$ students from $1-3$ grade possess classmate laptops, while only $2 \%$ do not possess them. 875 of the schools have internet access, while $13 \%$ do not have internet access. In the Republic of Macedonia, according to official data, $100 \%$ of schools have internet access.

\section{A. Teacher's professional development}

In the Republic of Macedonia, the law enables the teachers for professional development during their career [3].

The training for the use and implementation of information and communication technology in the education process is also involved in their professional development. Over the past ten years, teachers in the Republic of Macedonia have attended a large number of trainings on the use of ICT in the teaching and learning process. This way has been realized some projects such as e-School, with numerous trainings and high participation.

Among 620 interviewed teachers, $100 \%$ of them are using the technology in teaching, thanks to their professional development by attending different trainings and seminars on the implementation of ICT. $67 \%$ of teachers have attended seminars on the implementation of ICT in teaching, and 33\% haven't attended them.

\section{B. School plan and curriculum}

The curriculum preparation is done by the Bureau for
Development of Education and the same is adopted by the Ministry of Education and Science in the Republic of Macedonia. The curriculum suggests the use of ICT in the teaching and learning process with at least $30 \%$. This means that teachers are obliged to apply ICT in the teaching process, and at the same time are required to prepare their plans in electronic forms such as: lesson plans, daily preparations, worksheets, different printable or electronic tests, educational record, and pedagogical documentation. Around $95 \%$ of teachers prepare curricula and other additional materials and pedagogical documentation in electronic form, while $5 \%$ use them partially. $72 \%$ of teachers use over $30 \%$ of ICT in teaching, and $28 \%$ less than $30 \%$.

\section{Teachers demographics}

The demographic factor is very important for the teacher in using the Information and Communication Technology in the teaching process. The factors are:

$\begin{array}{ll}\text { - } & \text { Gender } \\ \text { - } & \text { Age } \\ \text { - } & \text { Teaching experience } \\ & \text { Level of education }\end{array}$

The approximate number of female teachers in primary education is $81 \%$ while $19 \%$ of teachers are males. $65 \%$ of teacher's age is 30-50 years. $39 \%$ of teachers have 0-10 years working experience, $29 \%$ have 11-20 years working experience, and $32 \%$ over 20 years working experience in education. $84 \%$ of teachers are graduated and $14 \%$ with master degree, while $2 \%$ with lower education levels.

\section{Skills and knowledge in ICT}

The teacher should possess competencies and skills to apply the ICT in the teaching process. As the most important competencies that the teacher should possess are:

$\begin{array}{ll}\text { - } & \text { The Internet } \\ \text { - } & \text { Word } \\ \text { - } & \text { Powcel } \\ \text { - } & \text { Database } \\ \text { - } & \text { Email } \\ \text { - } & \text { Smart Board, etc. }\end{array}$

The number of teachers who use Windows and Linux operating system is $58 \%, 31 \%$ of them use only Windows, while $11 \%$ use only the Linux operating system.

About $43 \%$ of teachers are able to use the operating systems, $53 \%$ have average level, while $4 \%$ have a low level of knowledge of operating systems. 90.5\% are using successfully the MS Word, MS Excel, MS PowerPoint, E-mail, electronic diary, electronic learning contents, Facebook or Twitter in the teaching process, while $9.5 \%$ partially. $51 \%$ of teachers use the educational platform in the teaching process, while $49 \%$ do not use them. $57 \%$ of teachers use electronic communication with their colleagues, school administration, the parents, students, etc., while $43 \%$ partially.

\section{E. Skills and knowledge in ICT}

Teachers motivation on using and implementing the ICT in teaching system has to do with the level of use of technology as well as other factors affecting the effective implementation of goals ranging from the available technology, the possibility of permanent pursuit of global trends in modern teaching. The attitude of teachers toward the implementation of ICT in teaching 
system should be considered to allow critical and self-critical access to the achieved effects.

Teachers have personal incentives to use ICT during teaching, so $74 \%$ of them have a positive opinion, while $26 \%$ do not have personal incentives. $56 \%$ of teachers think that the motivation in institutions is very small.

The majority of teachers, $67,5 \%$ think that the motivation of ICT implementation in teaching depends on the personal used skills, $12 \%$ is an inadequate level of education for implementation of ICT, while $20,5 \%$ have a lack of material motivation.

\section{F. Assessment of student achievement}

The assessment of student achievement by comparing the learning achievement with ICT and traditional learning achievements must be done continuously to a more realistic insight into the impact of ICT on teaching results.

For this reason the majority of teachers-61\% is against external electronic testing which is not giving a real insight of student's knowledge with ICT use.

\section{G. Knowledge acquisition from ICT}

Teachers and relevant institutions should verify the sustainability of student's knowledge with ICT use to revise the eventual release which would enable students to acquire knowledge and competencies in a more creative and sustainable way from the use of ICT by teachers and students.

Around $69 \%$ of teachers believe that teaching effects using ICT are more efficient than traditional teaching and this opinion is based on researches and results followed in continuity.

$82 \%$ of teachers believe that students are maximally supporting the use of ICT in teaching and learning process, while $18 \%$ are supporting it partially.

$75 \%$ of teacher's opinions are that the ICT use in the teaching process develops life competencies and skills of students with ICT use are more sustainable than traditional teaching.

$67 \%$ of teachers think that the acquisition of knowledge and competencies with ICT use are more sustainable than traditional teaching.

$67 \%$ of students are following in continuity the world trends of ICT use in education and the same per cent think that students who are attending classes with ICT are more successful in further education.

\section{H. Professional application of knowledge}

For more efficient implementation of teaching process, teachers have to use professionally the knowledge of ICT

The following aspects of professional implementation of ICT are:

- The creation of materials used by students, such as worksheets, tests, feedbacks, etc.

- Access to good teaching practices.

- The administration of the teaching programmer such as planning, monitoring, evaluation and reports.

- Cooperation with colleagues or ICT professionals.

- Electronic communication with students and their parents.

- The announcement of data, information, works, presentations, and student's creative work in Webs.

Online professional learning using different education platforms $95 \%$ of teachers create electronic materials that used students.

Approximately $58 \%$ of teachers use the best teaching practices of other teachers. $97 \%$ of teachers provide: planning, monitoring, evaluation and reports in electronic form $68 \%$ of teachers collaborate with their colleagues within the assets for the ICT use in teaching process $57 \%$ of teachers communicate in electronic forms with students or their parents.

$\dot{I}$. The commitment of the Ministry of Education and Science (MES) and the Ministry of Information Society and Administration (MISA) in Further Implementation of ICT in Teaching Process

MES and MISA care about the implementation of ICT in teaching through different portals and their professional development in the competency development on ICT use in the teaching process [4].

The MES in collaboration with Intel Company have created 513 electronics content for primary and secondary school students in 2010, which are used with a great success and this trend will continue in 5 and 10 next years based on the National Strategy for e-content for quality education. The MES and Microsoft Company have signed the memorandum of understanding and on this occasion organize different training to teachers for professional development emphasizing the organized competitions in state-level under the network Partners in Learning, where the Republic of Macedonia demonstrates winning the first places in European and world level through the qualities of ICT implementation in the teaching process [5].

For more qualitative learning, in 2014 it is planned to distribute to 1-3 grade students Tablets for that will help them use rationally and effectively books and other contents in electronic forms in the classroom and at home [6]. For this reason the working group is created for implementation of this project.

The portal of the MES, www.e-ucebnici.mk publishes electronically over $90 \%$ of the books of primary and secondary school with open source, which are effectively utilized by students and their teachers. The Electronic Diary is managing the pedagogical records and communication with parents within the MES [7].

There are recorded about 300000 students of primary and secondary schools and the same number of parents who have access to their success and activities [8].

In the Republic of Macedonia in the academic year 2012/2013 there was an external testing conducted for all students of primary and secondary schools. For the first time, the testing was conducted in electronic form and according to the State Commission Data, external testing was successful and the average grade at the state level was satisfactory.

According to surveys realized with 620 teachers, 395 of teachers support the external testing and $61 \%$ do not support it because of the impact of the test results on the final grade and success of students and teachers. The teacher who has 2 grade differences within two tests will be sanctioned with $20 \%$ cut in salary for a period of one year and the teacher with real assessment is rewarded with $15 \%$ of salary for a period of one year.

The ICT implementation in teaching process has increased the student success on the state level within the last two years based on the analysis of State Centre [9].

\section{J. Teachers challenges of ICT teaching}

According to a survey in RM, most of the teachers opinion is that demands of educational institutions are excessive with administrative formalities: such as all types of curricula, the global, thematic, operative, daily curricula with additional ICT planning, Eco standards, planning of extracurricular activities, 
free activities, excursion and hiking programs, planning the homework assignments and all these types in electronic and printed form have wiped out the creativity of teachers in successful realization of teaching.

Most of the people support ICT in teaching but the completion of pedagogical documentation in a slow electronic diary and with occasional omission is creating the anti-ICT climate in the teaching process.

According to the requirements of the Ministry of Education, in each subject at least $30 \%$ of teaching activities should include ICT. Younger teachers, generally accept this challenge and in some cases go beyond this request. For older teachers it is only about fulfilling the legal requirements in terms of time/number of activities, and are generally irritated from the sanctions following non-implementation of ICT.

\section{Conclusion}

In a government-led project called "A computer for every student", the primary and secondary schools in the Republic of Macedonia have been equipped with computers. These computers were scheduled to run on an educational version of the operating system Linux - Ed Ubuntu 7.04 (2007 version, month 4). Since then, no updates were made. School staff does not dare to reinstall new versions, even if now the Linux-13.10 (year 2013, month 10) is in use. With older version teachers and students have difficulties in implementation of different electronic contents. The same problem is caused by laptop donation to teachers and low-performing (1-3 grade) students. Therefore a large part of teachers request to have an opportunity to follow software changes and to not become a slave for the narrow interests of ICT.

Teacher's professional development was at an appropriate level in previous years, but with the rapid development of technology their requests for attending trainings and seminars are reasonable and more than necessary. In another example, this academic year in 66 schools have been installed Smart Boards, a technology that requires a completely different approach to teaching. Trainings for the technical aspects of using these devices have been organized in these schools, but these trainings do not include the didactic aspects of teaching using these devices.

It is planned that in 2014, low-performing students (1-3 grades) will receive tablets for qualitative learning. Absurdly, teachers who are teaching in these classes will not receive one. The lack of necessary appropriate technology and certainly no adequate training, for sure will negatively impact the usage of tablets inside the classroom. Knowing that students' skills for ICT use are usually in higher level than teachers' skills, there is a need to focus on adequate training of teaching staff even before such technology is made available in the classrooms.

Although, many teachers have important remarks regarding the implementation of ICT in classrooms, generally they are of the opinion that primary and secondary schools should use educational platforms and closed networks in order to improve the communication between teachers, students and parents and that this approach will increase the quality of the teaching process of thanks to ICT.

\section{References}

[1] Nacionalna strategija za razvoj na elektronski komunikacii so informaticki tehnologii 2005 - 2015, str. 19.

[2] Programi nacional për zhvillimin e arsimit në Republikën e Maqedonisë. 2005 - 2015 faq. 396.

[3] Ligji për Arsimin Fillor, Neni 91.

[4] www.schoool.mk and www.eduvideo.org.mk

[5] Microsoft Educator Network, www.pil-network.com

[6] E-books project, www.e-ucebnici.mk

[7] E-diary project, www.ednevnik.edu.mk

[8] Drzaven Zavod za Statistika, http://www.stat.gov.mk

[9] Drzaven Ispiten Centar, http://www.dic.edu.mk 